
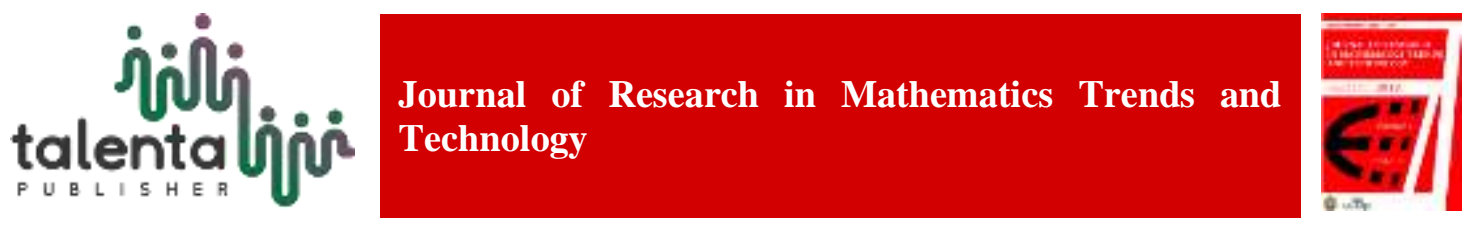

\title{
Usage Pattern Exploration of Effective Contraception Tool
}

\section{Endang Wahyu Handamari}

Department of Mathematics, University of Brawijaya, Malang, Indonesia

\begin{abstract}
Determination of contraception tool used by acceptors to support the Family Planning ("Keluarga Berencana") is a problematic. In choosing contraception tool, the acceptor must consider several factors, namely health factor, partner factor, and contraceptive method. Each contraception tool which is used has its advantages or disadvantages. Although it has been considering the advantages and disadvantages, it is still difficult to control fertility safely and effectively. So, an acceptor change a contraception tool used more than once. In order acceptors get the appropriate contraception tool then the patterns of changing in the usage of effective methods or contraception tool is determined. One of the methods that can be used to look the patterns of changing in the usage of contraception tool is data mining i.e. an extraction of large amounts of data. A pattern is said to be interesting if the pattern is not trivial, implicit, previously unknown, and useful. The patterns presented should be easy to understand, can be applied to data that will be predicted with a certain degree, useful, and new. The early stage before applying data mining is using $k$ nearest neighbors algorithm to determine the factors shortest distance selecting the contraception tool. The next step is applying data mining to usage changing data of method or contraception tool of family planning acceptors which is expected to dig up information related to acceptor behavior pattern in using the method or contraception tool. Furthermore, from the formed pattern, it can be used in decision making regarding the usage of effective contraception tool. The results is the $k$ nearest neighbors by using the Euclidean distance can be used to determine the similarity of attributes owned by the acceptors of Family Planning to the training data is already available. Based on available training data, it can be determined the usage pattern of contraception tool with the concept of data mining, where the acceptors of Family Planning are given a recommendation if the pattern is on the training data pattern. Conversely, if the pattern is none match, then the system does not provide recommendations of contraception tool which should be used.
\end{abstract}

Keywords: Contraception, Acceptors, Data Mining, k Nearest Neighbors

\begin{abstract}
Abstrak. Penentuan metode atau alat kontrasepsi oleh akseptor untuk mendukung Keluarga Berencana adalah suatu masalah. Dalam memilih alat kontrasepsi, akseptor harus mempertimbangkan faktor kesehatan, faktor pasangan, dan metode kontrasepsi. Setiap alat kontrasepsi yang digunakan memiliki kelebihan atau kekurangan, tetapi masih sulit untuk mengontrol kesuburan dengan aman dan efektif. Karenanya, akseptor mengubah alat kontrasepsi yang digunakan lebih dari satu kali. Agar akseptor mendapatkan alat kontrasepsi yang tepat maka pola perubahan dalam penggunaan alat kontrasepsi yang efektif ditentukan. Salah satu alat yang dapat digunakan untuk mencari pola perubahan dalam penggunaan alat kontrasepsi adalah penambangan data, yaitu ekstraksi pola yang menarik dari data berukuran besar. Suatu pola dikatakan menarik jika polanya berharga, tersirat, belum pernah diketahui, dan bermanfaat. Pola-pola yang disajikan harus mudah dipahami, dapat diterapkan pada data yang akan diprediksi dengan derajat tertentu, bermanfaat, dan baru. Tahap awal adalah menggunakan algoritma $k$ nearest neighbors untuk menentukan faktor jarak terpendek memilih alat kontrasepsi.
\end{abstract}

*Corresponding author at: University of Brawijaya, Malang, Indonesia

E-mail address: ewahyu-math@ub.ac.id 
Selanjutnya, melakukan penambangan data pada data perubahan penggunaan alat kontrasepsi akseptor KB yang diharapkan menggali informasi terkait pola perilaku akseptor dalam menggunakan alat kontrasepsi. Dari pola yang terbentuk, dapat digunakan dalam pengambilan keputusan mengenai penggunaan alat kontrasepsi yang efektif. Diperoleh hasil bahwa k-nearest neighbors dengan menggunakan jarak Euclidean dapat digunakan untuk mengetahui kesamaan atribut yang dimiliki oleh akseptor KB dengan data percobaan yang sudah tersedia. Dari data percobaan yang tersedia, dapat ditentukan pola penggunaan alat kontrasepsi dengan konsep data mining, di mana akseptor KB diberi rekomendasi jika pola tersebut ada pada pola data pelatihan. Sebaliknya, jika polanya tidak cocok, maka sistem tidak memberikan rekomendasi alat kontrasepsi yang sebaiknya digunakan.

Kata Kunci: Kontrasepsi, Akseptor, Penambangan Data, $k$-Nearest Neighbors

Received 15 November 2018 | Revised 21 January 2019| Accepted 28 February 2019

\section{Introduction}

Population problem in Indonesia which has a positive growth rate is a national problem in achieving development goals. These conditions will make problems in efforts to increase and the equitable distribution of public welfare. The growth rate is likely to increase so that if it is not controlled, it is predicted that in 2035 the population of Indonesia amounted to 305.6 million people. Therefore, it is necessary to do a cooperation and commitment of the government and society in an effort to reduce the rate of birth. The cooperation is realized in the form of development programs KKB (Kependudukan dan Keluarga Berencana). This KKB program was initiated since 1951 and has been experiencing growth. In 1970, the government formed Badan Koordinasi Keluarga Berencana Nasional (BKKBN). The BKKBN program includes thinning pregnancy by using contraceptive methods and creating economic prosperity for the society through the efforts of controlling and planning the population.

The contraception tool used by acceptors especially women should consider several factors. It concerns with the implications that may occur can not be known before usage. Therefore, it makes the acceptors of Family Planning possible to change contraception tool they use. An acceptor may change the contraception tool more than once until the acceptor feel comfortable and not problematic. Factors that are often being consideration in choosing a contraception tool are health factor, partner factor and factor of contraception methods. Medical history, among them are the menstrual cycle, degenerative diseases, blood pressure are included to health factor. Income level, frequency of intercourse, are some examples of partner factor. While the cost of contraception tool usage and security/risk is one example of contraception method factor. Research about classification of choosing potential contraception tool (has a big enough opportunity for success rate) using methods Naive Bayes classification has been done which after that implemented in the form of an application program [1]. With the same acceptors data, research on comparative methods Naive Bayes Classifier with Backpropagation Neural Network algorithm has been done [2].

In this research, the pattern of usage changing of effective contraception tool based on the primary data of Family Planning acceptors. The ascceptors which becomes the research object are the acceptors that change the contraception tool more than once. The method used in searching the pattern is $k$-Nearest Neighbors $(k N N)$ algorithm to determine the shortest distance of several determining contraception tool factors and Generalized Sequential Pattern algorithm which is one of data mining algorithms. 


\section{Materials and Methods}

\subsection{Data Source}

The data used in this study is the data taken from the acceptors of Family Planning in the subdistrict of Jagir, Surabaya municipality.

\subsection{Data Analysis}

In the data analysis, the required data are:

a) Eleven factors (attributes) that affect acceptors in determining contraception tool. The first factor is the partner factor which contains: wife age, frequency of intercourse, acceptors educational level, acceptors job. The second facto is the health factors include: health status which includes weight, height, blood pressure (systole and diastole), the frequency of menstruation, and hereditary disease. The third factor is the factor of contraceptive method which is the cost incurred. While contraception tools that are used include condom, IUD (Intra Uterine Device), pills, Family Planning injection, implants and MOW.

b) The last using of contraception tool.

c) The pattern of usage changing of contraception tool.

\subsection{The Stages of Research}

The stages used in this research includes:

a) Identifying the problem and formulation of the problem.

b) Collection the secondary data of family Planning acceptors in the Jagir sub-district, Surabaya municipality, which is the data related to eleven attributes and the patterns of usage changing of contraception tool.

c) Data processing of questionnaires result from eleven attributes by finding the shortest distance of training data using $k$ Nearest Neighbor method. $k$-Nearest Neighbors ( $k N N)$ algorithm is an algorithm that has the toughness in managing training document in large quantities and has a lot of noise. The process of $k N N$ algorithm is to choose a training document of $k$ ( $k$-values) that is located closest to tested document. Training document category that are most appeared/found in some nearby $k$, which is later selected as a predicted category to the tested document[3].

d) Determining for Family Planning acceptors pattern based on subsequence of $k$ selected data through sequence pattern mining. Sequence pattern mining is used to find data that have a sequence, such as a sequence of usage changing of contraception tool. The process of sequence pattern mining occurs if given a number of sequence, where each sequence contains some elements and some elements consist of items may also be given a value of minimum support. Sequential pattern exploration is finding all subsequence whose frequency of occurrence is greater than the minimum support [4]. The completion of the sequential problems can be done by several methods such as the Generalizes Sequential Pattern [5]. 


\section{Results and Discussion}

\subsection{Retrieval of Acceptor Data}

The sampling for the research object is done on secondary data consists of data of Family Planning acceptors of Jagir sub-district, Surabaya municipality. Data obtained in the form of quantitative data and qualitative data. The data includes qualitative and quantitative data are given in Table 1 below.

Table 1 Qualitative data and quantitative data from the questionnaire results of family planning acceptors and contraception tool

\begin{tabular}{llllll}
\hline No. & \multicolumn{1}{c}{ Qualitative Data } & No. & \multicolumn{1}{c}{ Quantitative Data } & No. & Contraception \\
\hline 1. & Degenerative disease & 1. & Menstrual cycle & 1. & Condom \\
2. & Highest education & 2. & Age & 2. & IUD \\
& acceptor & 3. & Weight & 3. & Pills \\
3. & Highest education of & 4. & Height & 4. & Family Planning \\
& husband's acceptor & 5. & Blood pressure (diastolic) & & Injection \\
4. & Acceptor's job & 6. & Blood pressure (systolic) & 5. & Implant \\
& & 7. & Frequency of intercourse & 6. & MOW \\
\hline
\end{tabular}

The sourcecode for determining $k$ closest distance of acceptors data with eleven factors of data using $k$ Nearest Neighbors ( $k N N)$ as follows:

The function to calculate the euclidean distance between the two private data

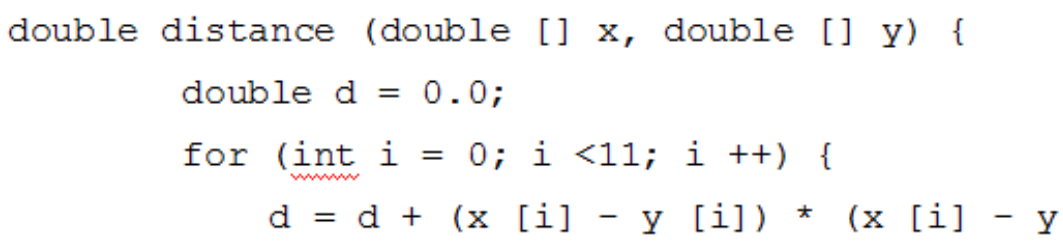

Figure 1 Syntax of the function to calculate

Followed by sorting the data index based on the shortest distance and the result is stored in an array. The final step is to use data mining techniques to look at the pattern of the test data to training data taken with the $k$ shortest distances. If the test data pattern is in $k$ training data pattern for the first time, then the system will provide final recommendations of contraception tool. If the pattern of test data is not in the $k$ training data, then the system cannot give recommendations of contraception tool which should be selected. For example :

Given following test data with 11 attributes and the pattern of contraception tool usage is 35 . Next, given 36 training data, by using Nearest Neighbor method, it is obtained Euclidean distance of test data to 36 training data as follows: 
Table 2 Euclidean distance of test data to 36 training data

\begin{tabular}{cccc}
\hline $\begin{array}{c}\text { Number of the } i \text {-th } \\
\text { Training Data }\end{array}$ & $\begin{array}{c}\text { Distance between the Test Data } \\
\text { to the Number of the } i \text {-th } \\
\text { Training Data }\end{array}$ & $\begin{array}{c}\text { Number of the } i \text {-th } \\
\text { Training Data }\end{array}$ & $\begin{array}{c}\text { Distance between the Test Data } \\
\text { to the Number of the } i \text {-th } \\
\text { Training Data }\end{array}$ \\
\hline 0. & 0.910 & 18. & 1.025 \\
1. & 1.456 & 19. & 1.030 \\
2. & 1.230 & 20. & 1.141 \\
3. & 1.141 & 21. & 1.216 \\
4. & 0.972 & 22. & 1.046 \\
5. & 1.133 & 23. & 1.247 \\
6. & 1.043 & 24. & 1.104 \\
7. & 1.011 & 25. & 1.176 \\
8. & 1.080 & 26. & 0.997 \\
9. & 1.077 & 27. & 0.956 \\
10. & 1.042 & 28. & 1.199 \\
11. & 0.848 & 29. & 1.098 \\
12. & 1.049 & 30. & 1.009 \\
13. & 0.871 & 31. & 1.172 \\
14. & 1.211 & 32. & 0.905 \\
15. & 0.829 & 33. & 1.152 \\
16. & 0.995 & 34. & 1.069 \\
17. & 1.112 & 35. & \\
\hline
\end{tabular}

Table 310 nearest records after ordered from the smallest

\begin{tabular}{ccccc}
\hline No. & $\begin{array}{c}\text { Record } \\
\text { Order }\end{array}$ & $\begin{array}{c}\text { Euclidean Distance } \\
\text { to the Test Data }\end{array}$ & $\begin{array}{c}\text { Consumption } \\
\text { Pattern }\end{array}$ & True/False \\
\hline 1 & 15 & 0.829 & 563 & False \\
2 & 11 & 0.848 & 645 & False \\
3 & 13 & 0.871 & 635 & True \\
4 & 33 & 0.905 & 345 & True \\
5 & 0 & 0.910 & 365 & True \\
6 & 28 & 0.956 & 345 & True \\
7 & 4 & 0.972 & 415 & False \\
8 & 27 & 0.994 & 516 & False \\
9 & 16 & 0.995 & 361 & False \\
10 & 31 & 1.009 & 365 & True \\
\hline
\end{tabular}

Therefore, the test data that contains eleven attributes and contraception tool pattern 35 is given a recommendation to use contraception tool, namely Implant (see Table 1), because it has a short Euclidean distance and suitable pattern for the first time.

\section{REFERENCES}

[1] S. Abusini, "Klasifikasi Pemakaian Alat Kontrasepsi yang Potensional dengan Metode Naïve Bayes Classifier", Laporan Penelitian BOPTN DIKTI, 2013.

[2] E. Wahyu, K. Andawaningtyas and S. Abusini, "Comparison of Naïve Bayes Classifier and Back Propagation Method to Determine Suitable Contraception", Proceeding of the First International Conference on Science (ICOS - 1), 2014.

[3] R. Al-Shalabi, G. Kanaan and M. Gharaibeh, "Arabic Text Categorization using kNN Algorithm", Proceedings of the $4^{\text {th }}$ International Multi-conference on Computer Science and Information Technology, Amman, Jordan, pp. 1-9, 2006.

[4] R. Agrawal and R. Srikant, "Fast Algorithms for Mining Assocoation Rules", Proceeding of the $20^{\text {th }}$ International Conference on Very Large Databases, Chile, 1994.

[5] R. Srikant and R. Agrawal, "Mining Quantitative Association Rules in Large Relational Tables", Association for Computing Machinery (ACM) SIGMOD Record, vol. 25, no. 2, pp. 1-12, Jun. 1996. 